\title{
Enfekte Gökkuşağı Alabalıklarının Böbrek Dokusu Kolinerjik Sistem Enzimlerinin Değișimi
}

\author{
Aslı Çilingir Yeltekin ${ }^{1 *}$ \\ 1*Van Yüzüncü Yıll Üniversitesi, Fen Fakültesi, Kimya Bölümü, Van, Türkiye, (ORCID: 0000-0003-0071-7434), aslicilingir@yyu.edu.tr
}

(İlk Geliş Tarihi Aralık 2020 ve Kabul Tarihi Ocak 2021)

(DOI: 10.31590/ejosat.842539)

ATIF/REFERENCE: Çilingir Yeltekin, A. (2021). Enfekte Gökkuşağı Alabalıklarının Böbrek Dokusu Kolinerjik Sistem Enzimlerinin Değişimi. Avrupa Bilim ve Teknoloji Dergisi, (22), 258-262.

\section{$\ddot{O} \mathbf{z}$}

Besin maddeleri arasında su ürünlerinin önemi her geçen gün artmakta ve buna bağlı olarak da balık yetiştiriciliği hızla gelişmektedir. Balık yetiştiriciliğinde artan üretime paralel olarak hastalık problemleri de ortaya çıkmaktadır. Yüksek stoklama yoğunluğu, bakteriyel hastalıkların yaygın olarak görülmesine ve bu durumda balık metabolizmasında bozulmalara sebep olmaktadır. Bu nedenle bu çalışmada; alabalık çiftliklerinde enfeksiyon oluşturan başlıca bakteriyel ajanların bulunduğu gökkuşağı alabalıkları tespit edilmiş ve PCR ile bu bakteri türleri (Staphylococcus epidermidis, Lactococcus garvieae ve Bacillius subtilis) belirlenmiştir. Çalışmada bakteri ile enfekte oldukları belirlenen alabalıkların böbrek dokularında kolinerjik sistemin santral ve periferik sinir sistemi hücreleri arasında uyarıların taşınmasında görevli Asetilkolin esteraz (AChE) ve Bütirilkolin esteraz (BChE) enzim düzeyleri araştırılmış olup, sağlıklı balıklar ile karşılaştırılarak belirlenen değişimler değerlendirilmiştir. Her üç bakteri ile enfekte olan alabalıkların kolinerjik sistemin enzim seviyelerinin kontrol grubuna göre azaldığı tespit edilmiştir $(\mathrm{p}<0.005)$.

Anahtar Kelimeler: AChE, Bakteri, BChE.

\section{Kidney Tissue of Infected Rainbow Trout Changes in Cholinergic System Enzymes}

\begin{abstract}
The importance of seafood among nutrients is increasing day by day and fish farming is developing accordingly. Disease problems arise in parallel with the increasing production in fish farming. High stocking density causes widespread bacterial diseases and thus impairment in fish metabolism. Therefore, in this study; Rainbow trout containing major bacterial agents causing infection in trout farms in our province were identified and these bacterial species (Staphylococcus epidermidis, Lactococcus garvieae ve Bacillius subtilis) were determined by PCR. It was investigated how Acetylcholine esterase (AChE) and Butyrylcholine esterase (BChE) enzyme levels in the kidney tissues of the trout determined to be bacterial in the cholinergic system to carry the impulses between central and peripheral nervous system cells compared to healthy fish. It was determined that the enzyme levels of the cholinergic system decreased in all three types of bacteria compared to the control group $(\mathrm{p}<0.005)$.
\end{abstract}

Keywords: AChE, Bacteria, BChE.

\footnotetext{
*Sorumlu Yazar: aslicilingir@yyu.edu.tr
} 


\section{Giriş}

Nüfusun hızla artması besin üretiminin de hızla gelişen bir endüstri dalı olmasına sebep olmuştur. Su ürünleri alanında da artan bu üretim endüstriyel bir sanayi dalı olarak yoğun üretim yapan çiftliklere dönüşmüştür. Bunun sonucu olarak yoğun balık yetiştiriciliği yapılan çiftliklerde enfeksiyona sebep olan bakteriyel hastalıkların görülme sıklığı artmıştır. Özelliklede zoonoz bakteri türleri ile enfeksiyon durumu insan sağlığ açısından ayrıca bir önem arz etmektedir. Balık üreticileri açısından da bakteriyel enfeksiyonlar büyük ekonomik önem arz etmektedir (Aydın, 2009).

Canlı dokularında bakteriyel enfeksiyonlar hem gelişmede gecikmeye hemde bağışıklı sisteminde, savunma mekanizmalarında ve enzim sistemlerinde olumsuz etkilere sebep olmaktadır (Aydın, 2009). Enzimler, çoğunluğu protein yapısında olan ve canlılardaki biyokimyasal tepkimeleri gerçekleştiren biyokatalizörlerdir. Enzimler reaksiyonların hızlarını artırmalarına ilaveten hücrelerde metabolik yolaklar için önemli birçok reaksiyonun hızını düzenlerler. Merkezi kolinerjik sistem, hücre gövdelerinin ve dendritlerin karmaşık bir bileşenidir. Hayvan kolinesterazları, kolinerjik ve kolinerjik olmayan dokularda, ayrıca plazma ve diğer vücut sıvılarında bulunan yaygın enzimlerdir (Massouliè ve ark., 1992; Chatonnet ve Lockridge, 1989; Yeltekin ve ark. 2018). Kolinasetiltransferaz (ChAT), asetilkolin (ACh), kolinesterazlar (Asetilkolinesteraz (AChE E.C. 3.1.1.7) ve butirilkolinesteraz (BChE E.C. 3.1.1.8)), kolinerjik reseptörler (muskarinik reseptörler (MR) ve nikotinik reseptörler (NR)) kolinerjik sistemin bileşenleridir. Bu enzimler substrat özgüllüklerine, aşırı substrattaki davranışlarına ve inhibitörlere duyarlılıklarına göre ayrılmışlardır. AChE, nörotransmitter asetilkolini (ACh) kolinerjik sinapslarda ve nöromüsküler sinapslarda hızla koline ve asetata hidrolize eden ve böylece kolinerjik sinir iletimde önemli bir rol oynayan, sinir sisteminin en etkili enzimlerinden biridir (Şekil 1). AChE, asetilkolini diğer kolinörlerden daha hızlı hidrolize eder ve butirilkolin üzerinde daha az etkindir. Aksine, BChE tercihen butirilkolin üzerine etki eder, fakat aynı zamanda asetilkolin'i hidrolize eder (Chatonnet ve Lockridge, 1989; Ekholm, 2001). AChE'nin aşırı substrat tarafından inhibe edilmesi, onu BChE'den ayıran temel özelliklerden biridir. BChE substratı aşırı substratta aktivasyon sergilemektedir. ACh'nin AChE tarafindan hidrolizi, asetilasyon ve deasetilasyon işlemlerinin dahil olduğu bir reaksiyon sonucunda oluşmaktadır (Tougu, 2001).

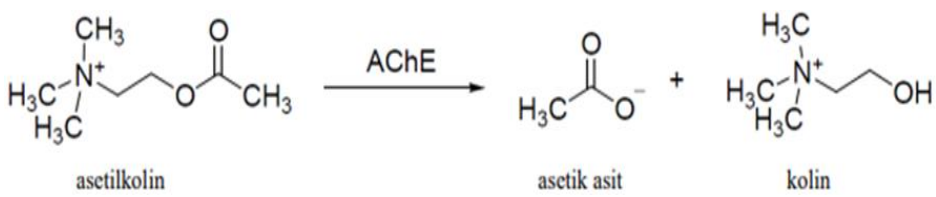

Şekil 1. Asetilkolinin asetilkolinesteraz tarafindan hidrolizi

Çeşitli in vivo ve in vitro çalışmalar AChE enziminin çeşitli morfometrik süreçlerde, sinir sistemindeki hücre farklılaşması ve sinaptojenezde, hücre adezyonunda ve göçünde, apaptotik yolaklarda etkili olduğu gösterilmiştir. Bu çalışmada, Farklı bakteriler ile enfekte olan Oncorhynchus mykiss balıklarının böbrek dokusu asetilkolinesteraz ve bütirilkolinesteraz düzeylerinin değişiminin araştırılması amaçlanmıştır.

\section{Materyal ve Metot}

\subsection{Balık}

Bu çalışmada 45 adet 200-250 g'lık alabalıklar ticari olarak üretim yapan alabalık üretim çiftliklerinden temin edilmiştir Hasta oldukları gözlemsel olarak tespit edilen Gökkuşağı Alabalıkları (Oncorhynchus mykiss Walbaum 1792), bakteriyel hastalıkları tespit edilmek üzere laboratuvar ortamına getirilmiştirLaboratuvar ortamında bakteriyel analiz için çalışılacak dokulardan örnekler alındıktan sonra biyokimyasal analiz için böbrek dokuları ayrılmıştır.

\subsection{Bakteriyel Hastalıkların Tespiti ve İzolasyonları}

Çalışma Van Yüzüncü Yıl Üniversitesi, Hayvan Deneyleri Yerel Etik Kurulu'nun 31.01.2019 tarih ve 2019/01 sayılı kararı ile gerçekleştirilmiştir. Çalışmada kullanılan gökkuşağ alabalıkları Van ilinde bulunan ve yavru üretimi yapan işletmelerden seçilmiştir. Bu amaçla 5 farklı işletmeden 9'ar adet olmak üzere toplam 45 adet alabalık satın alınmıștır. Örnekleme yapılan balıklarda dış semptom olarak hareketlerde yavaşlama, ayrı yüzme, renkte kararma, bilateral ekzoftalmus ve asites gibi semptomlar başta olmak üzere yüzme bozukluğu, yüzgeç erimesi gibi belirtiler gösteren balıklar seçilmiştir.

Bakteri izolasyonları ve moleküler tabanlı çalışmalar Van Yüzüncü Yıl Üniversitesi, Biyoteknoloji Uygulama ve Araştırma Merkezine ait laboratuvarda gerçekleştirilmiştir. Örnekleme yapılan balıklardan bakteri izolasyonlarını gerçekleştirilmesi amaciyla Tryptic Soy Agar (TSA) besi yerine böbrek ve semptomlu yüzgeç dokularından ekimler swap yardımı ile gerçekleştirilmiştir. 24 saatlik inkübasyon peryodunun ardından gelişen koloniler tekrar saflaştırılmıştır. Saflaştırılan izolatların besiyeri görüntüleri aşağıda verilmiştir (Şekil 1). 5 farklı çiftlikten 3 çeşit bakteri türü gelişimi gözlenmemiştir. Çiftliklerden sırasıyla 10 adet $L$. garvieae, 9 adet $S$. epidermidis ve 8 adet $B$. Subtilis, etkenleri izole edilmiştir.

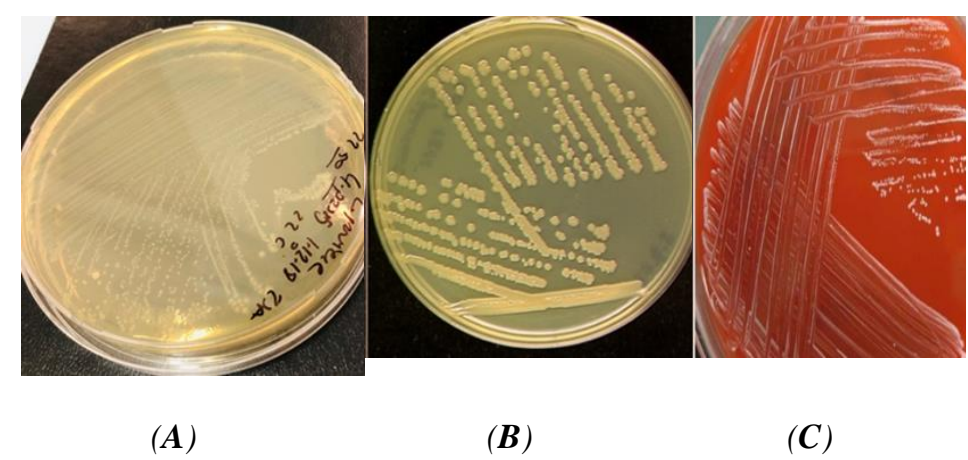

Şekil 2. Gökkuşă̆ alabalı̆̆ işletmelerinden izole edilen bakteriyel hastallk etkenleri (A: L. garvieae, B: B. subtilis, C: S. epidermidis) (Kurt, 2019).

\subsection{Bakterilerin İdentifikasyonu ve Real-Time PCR Analizi Sonuçları}

Bakterilerin identifikasyonları için 27F-1492R universal primeler kullanılarak Real-Time PCR uygulanmıştır. Bu amaçla bakterilerden DNA izolasyonları Mericon bacterial DNA kiti (Qiagen) ile gerçekleştirilmiştir. DNA'ların saflıkları Nanospektrofotometre (Thermo) ile ölçülmüştür. Real-Time 259 
PCR bakterilerden izole edilen DNA'lar ve universal primerler kullanılarak gerçekleştirilmiştir. Çalışmada kullanılan Real-Time protokolü aşağıda verilmiştir (Tablo 1).

Tablo 1. Real-Time PCR aşamasında kullanılan protokol (Kurt,

\begin{tabular}{|c|c|c|c|}
\hline & & $\begin{array}{l}\text { Sicaklık } \\
\left({ }^{o} \mathrm{C}\right)\end{array}$ & $\begin{array}{c}\text { Zaman } \\
\left(d k,{ }^{*} s n\right)\end{array}$ \\
\hline Ön-denatürasyon & & 95 & 10 \\
\hline Denatürasyon & & 94 & $45^{*}$ \\
\hline Bağlanma & 45 döngü & 56 & $30^{*}$ \\
\hline Uzama & & 72 & $45^{*}$ \\
\hline Son uzama & & $72^{\circ} \mathrm{C}$ & 7 \\
\hline
\end{tabular}

2019)

İzole edilen bakteriyel etkenlerden elde edilen DNA'lar RealTime PCR'da template olarak kullanılmıştır. İzolatların PCR tanımlanması amaciyla Real-Time PCR işlemi gerçekleştirilmiştir. Universal (27F-1492R) primerler ile gerçekleştirilen Real-Time PCR sonucu aşağıda verilmiştir (Şekil 3). Real-Time PCR sonuçları doğrultusunda bakteriyel DNA'ların Universal primerler ile örtüşerek bağlanma meydana getirdiği SYBRGreen tabanlı florasan ışımada pozitif sonuçlar verdikleri gözlenmiştir.

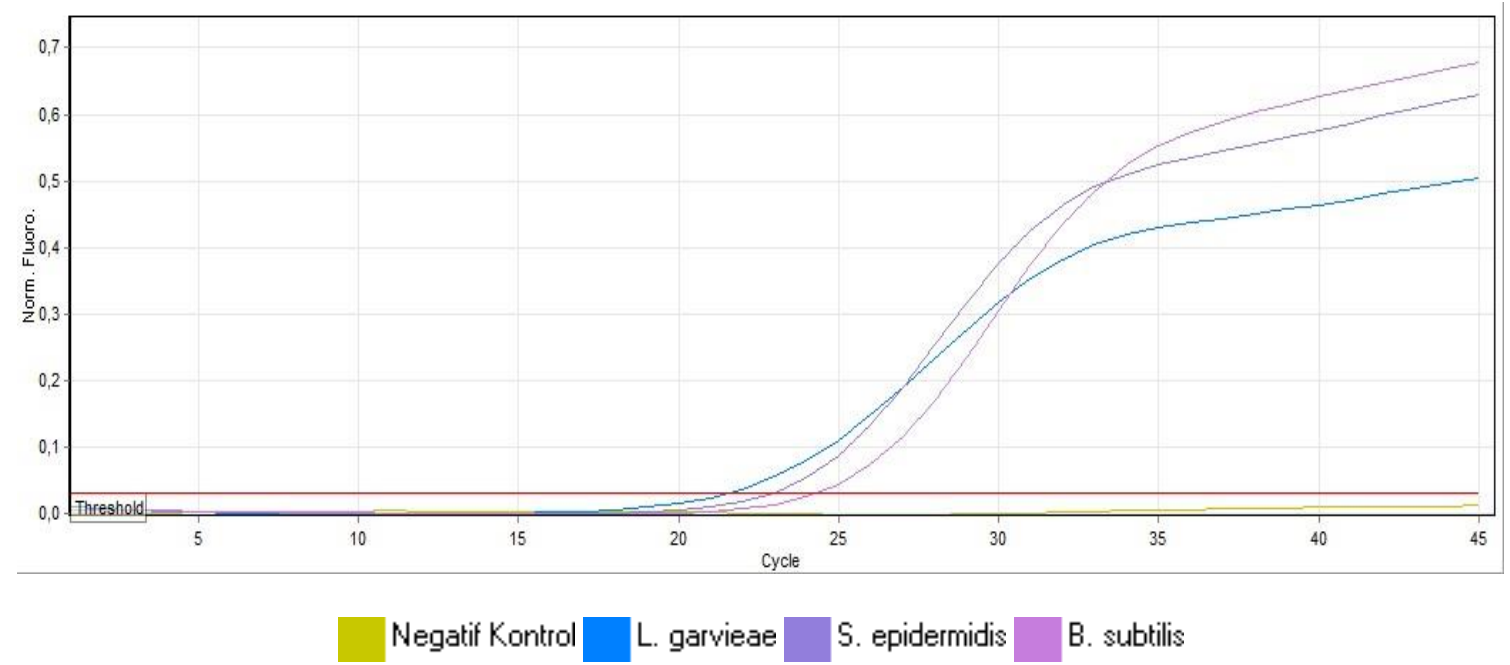

Şekil 3. Çalışmada izole edilen bakteriyel DNA'lar ile gerçekleştirilen Real-Time PCR görüntüsü (Sigmoidal eğriler pozitif, Eşik değerinin altından kalan negatif kontrol örneği) (Kurt, 2019).

\subsection{Biyokimyasal Analizler}

Bakterili alabalıklardan ve kontrol grubu alabalıklarından alınan böbrek dokuları fosfat tamponu (50 mM KH${ }_{2} \mathrm{PO}_{4}$ ve 10 $\mathrm{mM}$ EDTA) ile homojenize edilmiştir Homojenizatör ile homojen hale getirilen doku örneklerinin santrifüjleme işleminden sonra üstte kalan sıvı kısım alınıp biyokimyasal analizler için kullanılmıştır (Yeltekin ve Oğuz, 2018; Yeltekin, 2018).

Çalışmada Asetilkolinesteraz ve Butirilkolinesteraz aktivite analizleri Ellman ve ark. (1961)'nın kolorimetrik metoduna göre belirlenmiştir. Kolinesterazlar, asetiltiyokolinin tiyokolin ve asetata parçalanma reaksiyonunu katalize etmektedir DTNB'nin ürün olarak açığa çıkan tiyokolin oranı ile reaksiyonu sonucu sararan 5-tio-2-nitrobenzoik asitler oluşmaktadır. Oluşan ürünlerin renklerinin konsantrasyona göre değişiminden yararlanarak spektrofotometrede ölçümleri yapılmıştır. Hazırlanan karışımların absorbans değerleri iki tekrarlı olmak üzere spektrofotometre ile $412 \mathrm{~nm}$ dalga boyunda okunarak ölçümler yaplmıştır. Aynı örnek için yapılan ölçümler arasındaki korelasyona bakılarak ölçümler tekrarlanmıştır. Daha sonra böbrek dokusu edilen AChE ve BChE düzeyler (EU/mg) enzim aktivitesi olarak hesaplanmıştır.

\subsection{Verilerin istatistiksel analizi}

Analizler sonucunda elde edilen değerler ortalama \pm standart hata olarak ifade edildi. Farklı örnekleme alanlarından ortaya çıkan değerlerinin çoklu karşılaştırmaları için ANOVA testi ve gruplar arasındaki farklılığın belirlenmesi için Tukey testi kullanılmıştır. Değerler arasındaki fark 0.05 'e göre yapılmıştır.

\section{Araştırma Sonuçları ve Tartışma}

\subsection{Bulgular}

S. epidermidis, L. garvieae ve B. subtilis bakteriler ile enfekte olan Gökkuşağı alabalıklarının böbrek dokusu Asetilkolin esteraz düzeyleri kontrol grubu asetilkolin esteraz düzeyleri ile karşılaştırıldığında istatiksel olarak her üç bakteri grubunda da anlamlı azalış olduğu tespit edilmiştir $(\mathrm{p}<0.005)$ (Şekil 4). Bakteriler ile enfekte olan Gökkuşağı alabalıklarının böbrek dokusu Bütirilkolin esteraz düzeyleri kontrol grubu bütirilkolin esteraz düzeyleri ile karşılaştırıldığında $B$. subtilis ve L. garvieae bakterileri ile enfekte olan alabalık gruplarında istatiksel olarak anlamlı azalışların olduğu belirlenmiştir $(\mathrm{p}<0.005)$ (Şekil 5). Özelliklede L. garvieae bakterileri türü ile enfekte olan alabalık grubu düzeylerinin belirgin bir seviyede düştüğü gözlenmiştir. 


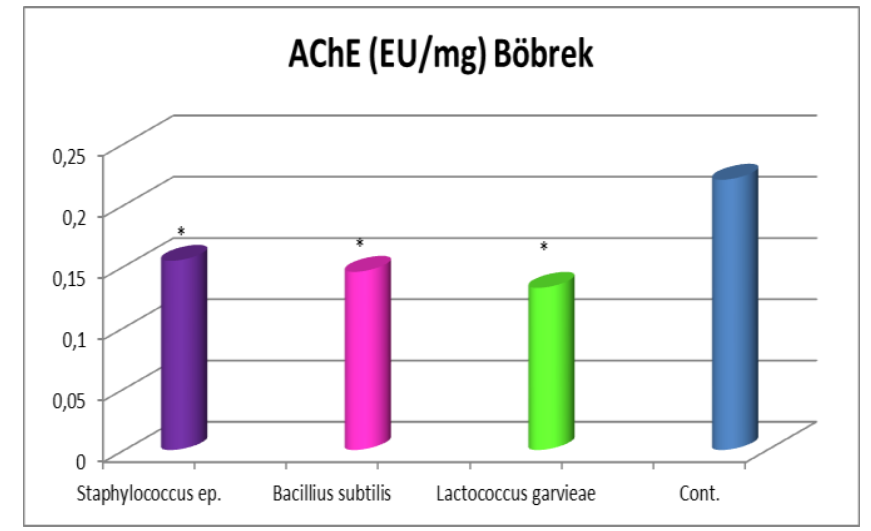

Şekil 4. Farklı bakteriler ile enfekte Gökkuşağı alabalıklarının böbrek dokusu AChE aktivite düzeylerinin değişimi.

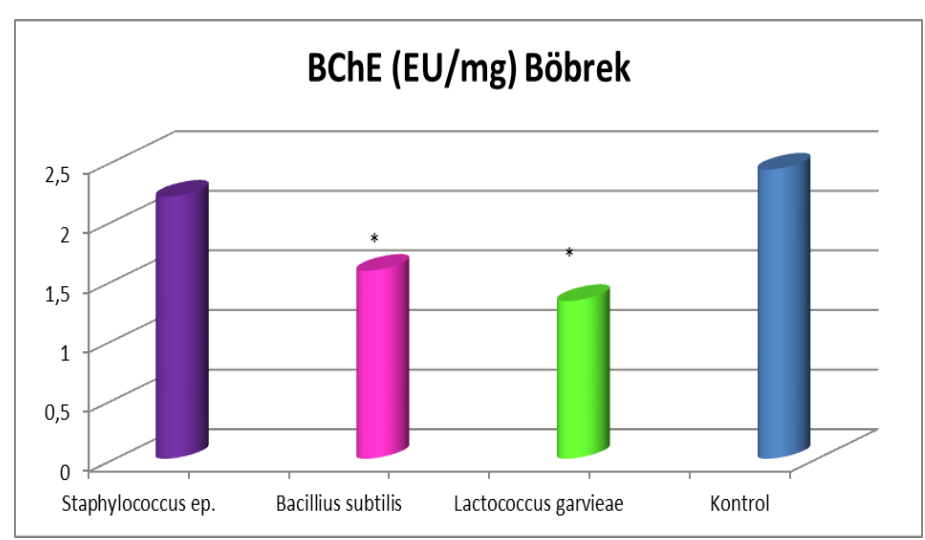

Şekil 5. Farkl bakteri türleri ile enfekte Gökkuşă̆ alabalıklarının böbrek dokusu BChE aktivite düzeylerinin değişimi.

\subsection{Tartışma}

Balıklar su içerisinde içerisin de sürekli olarak mikroorganizmalar ile temas halindedir. $\mathrm{Bu}$ sebeple bakterilerden kaynaklı enfeksiyon durumu balık çiftlikleri için büyük ekonomik kayıplara, neden olmaktadır (Tanrıkul ve ark., 1997). Türkiye'de tatlı su ve deniz balıklarındaki parazitlerle ilgili yapılan çalışmalar incelendiğinde, ilk olarak kupez balığından metazoon bir parazit olan Ceratothoa sp'nın bildirildiği ve daha sonra çeşitli araştırıcılar tarafindan da tatlı su, deniz ve çeşitli akvaryum balıklarının parazit faunalarının çalışıldığ 1 görülmüştür (Öktener, 2003). Enfeksiyoz hastalıkların ortaya çıkmasında konakçı, patojenin virülans ve çevre arasında bir ilişki söz konusudur. Çevre şartlarındaki olumsuz değişiklikler strese neden olurken hastalık etkeninin virülans ve miktarı da hastalığın çıkmasında önemli bir faktördür (Çağırgan, 1993). İlk zamanlarda 15-20 bakteri türünün balıklar için patojenik olduğu düşünülmesine rağmen daha sonra yapılan çalışmalarda balıklardan 70'e yakın bakteri türü izole edilmiştir (Austin ve Austin, 1993).

Metabolizmada Asetilkolin bir nörotransmitter olarak kullanır. Balıklarda da, bu nörotransmitter ile bağlantılı fonksiyonların bazıları şunlardır: optik devrelerin görsel yanıtı; tat alma sırasında bilgi işleme besleme ve motor bilgilerinin işlenmesi besleme sırasında tat bilgisi işleme ve motor bilgilerinin işlenmesi gibi (Clemente ve ark., 2004). Aeromonas caviae, balıklarda nadiren bulunan bir bakteri türüdür ancak enfekte olan balıklarda yüksek oranda ölüm görülmektedir. $\mathrm{Bu}$ bakteri ile enfekte olan Gümüş yayın balıklarının (Rhamdia quelen), böbrek dokusunda sağlıklı balıklara göre Asetilkolin esteraz ve bütirilkolin esteraz enzim düzeylerinin azalış gösterdiği tespit edilmiştir (Baldisseraa, ve ark., 2018). Acinetobacter, Bacillus, Corynebacterium, ve Pseudomonas bakterileri ile enfekte olan İşkine balıklarını (Sciaenops ocellatus) enzim sistemlerinin değişiminin araştırıldığı bir çalışma yapılmıştır. Bu çalışmada bakterilerin balıkların enzim sistemlerini tahribata uğrattığı ve bu tür kültür balıkçılığı için verimi olumsuz etkileyen bir durum olduğu belirtilmiştir (Tarnecki ve ark., 2018). Streptococcus agalactiae ile enfekte olmuş Gümüş yayın balıklarının (Rhamdia quelen), bakteri enfeksiyonu durumunda metabolizmada stres oluşumunu belirlemeye yönelik bir çalışma yapılmıştır. Çalışmada bakterili balıkların stres düzeylerinin kontrol grubuna göre belirgin bir düzeyde artış gösterdiği tespit edilmiştir (Souza ve ark., 2017). Aeromonas hydrophilla özellikle su ortamlarında bulunan bir bakteridir. Aeromonas hydrophilla ile enfekte olan yavru Hint balıklarının (Cirrhinus mrigala) bağışıklık sistemlerinin araştırıldığı bir çalışma yapılmıştır. Çalışmada bakteri ile enfekte olan yavru balıkların bağışıklık sisteminin zayıfladığı tespit edilmiştir (Kumar ve ark., 2018). Sunduğumuz çalışmanın sonuçları da bu literatürler ile uyumlu olarak enfeksiyon durumunda Asetilkolin esteraz ve Bütirilkolin esteraz düzeylerinin azaldığı gözlenmiştir.

\section{Sonuç}

Sonuç olarak; S.epidermidis, L. garvieae ve B. subtilis bakteri ile enfekte olan gökkuşağı alabalıklarının kolinerjik sistem enzimlerinden Asetilkolin esteraz ve Bütirilkolin esteraz düzeylerinin olumsuz olarak etkilendiği tespit edilmiştir. $\mathrm{Bu}$ durum mevcut bakterilerin alabalıkların kolinerjik sistem enzimlerinin salg1 metabolizmasında inhibisyona ya da denatürasyona sebep olasından kaynaklanmış olabilir. $\mathrm{Bu}$ nedenle bu çalışma ile balık yaşam alanlarının temizliğinin, hasta balık izolasyonunun, su kaynaklarının ve yemlerin kalitesinin önemine dikkat etmenin işletmeler için daha az canlı kaybı ve daha sağlıklı besin üretimi sağlanması bakımından önem arz edeceği ortaya konulmuştur.Ayrıca bakterili balıkların kolinerjik sistem üzerine etkileri hakkında çok sınırlı sayıda çalışma mevcuttur bu nedenle bu çalışmanın literatüre önemli katk1 sağlayacağı düşünülmektedir.

\section{Kaynakça}

Aydın, F. (2009). Salar Lınnaneus, Salmo., A.Ü. Alabalık Biyolojisi ve Yetiştirme Teknikleri

Austin, B. \& Austin, D.A. (1999). Bacterial Fish Pathogens Disease of Farmed and Wild Fish, Third (Revised) Edition, Praxis Publishing Chichester, U.K., 457.

Baldissera , M.D. , Souza, C. F., Doleski , P.H., Júnior, G.B., de Vargas, A.C., \& Baldisserotto, B., (2016). Involvement of cholinergic and purinergic systems during the inflammatory response caused by Aeromonas hydrophila in Rhamdia quelen. Microbial Pathogenesis, 99, 78-82.

Çağırgan, H., (1993). Kültürü yapılan çipura ve levrek balıklarında görülen bakteriyel hastalıkların teşhis ve tedavileri. Doktora Tezi. Ege Üniversitesi, İzmir. 
Chatonnet A. \& Lockridge O. (1989) Comparision of butyrylcholinesterase and Acetylcholin esterase. Biochemical Journal, 260, 625- 634.

Ekholm, M. (2001). Predicting relative binding free energies as substrate and inhibitors of acetyl- and butyrylcholinesterase. Journal of Molecular Structure: THEOCHEM, 572, 25-34.

Ellman, G.L., Courtney, K.D. \& Andres, V.J., (1961). A New and Rapid Colorimetric Determination of Acetylcholinesterase Activity. Biochemical Pharmacology, 7, 88-95.

Kumar, PJainb . K.K. \& Sardar, P., (2018). Effects of dietary synbiotic on innate immunity, antioxidant activity and disease resistance of Cirrhinus mrigala juveniles, Fish and Shellfish Immunology. 80, 124-132.

Kurt, F., (2019). Farklı Bakteriyel Hastalık Etkenlerine Maruz Kalmış Gökkuşağı Alabalıklarında Oluşan DNA Hasarı ve Antioksidan Düzeylerindeki Değişimlerin İncelenmesi Yüksek Lisans Tezi. Yüzüncü Yil Üniversitesi Fen Bilimleri Enstitüsü Kimya Anabilim Dalı. Aralık 2019, 77.

Massouliè, J., Pezzementi, L., Bon, S., Krejci, E. \& Valette, F.M. (1992). Molecular and cellular biology of cholinesterases. Neurobiology, 41, 31-91.

Öktener, A. (2003). A Checklist of Metazoan Parasites Recorded in Freshwater Fish from Turkey. Zootaxa, 394, 1-28.

Souza, C.F., Baldissera, M.D., Santos, R.C.V., Raffin, R.P. \& Baldisserotto, B., (2017). Nanotechnology improves the therapeutic efficacy of Melaleuca alternifolia essential oil in experimentally infected Rhamdia quelen with Pseudomonas aeruginosa. Aquaculture, 473, 169-171.
Tanrıkul, T., Çağırgan, H. \& Tokşen, E., (1997). Bacterial Fish Diseases. Journal of the Veterinary Control and Research Institute, Bornova, 20, 105- 27.

Tarnecki, A.M., Rhody, N.R., Walsh, C.J., (2018). Health Characteristics and Blood Bacterial Assemblages of Healthy Captive Red Drum: Implications for Aquaculture and Fish Health Management. Journal of Aquatic Animal Health, 30, 339-353.

Tougu V. (2001). Acetylcholinesterase: Mechanism of catalysis and inhibition. Curr. Journal of Medicinal Chemistry, 1, 155-170.

Yeltekin, A.Ç. \& Oğuz, A.R. (2018). Antioxidant responses and DNA damage in primary hepatocytes of Van fish (Alburnus tarichi, Güldenstadt 1814) exposed to nonylphenol or octylphenol. Drug and Chemical Toxicology, 41, 415.

Yeltekin, A.Ç. (2018). Comparison of Toxic Metal, Trace Element and Macro Element Levels in Trout Cultivated in Latvia and Turkey. Fresenius Environmental Bulletin, 27 (10), 7039-7044.

Yeltekin, A. Ç. , Karapinar, Z., \& Mis, L., (2018). The changes in the levels of elements in sheep with Contagious Ecthyma. Indian Journal Of Anımal Research, 52: 5660. 